\section{Quantifying the Cooling Period for Flowering of 'Nellie White' Easter Lily}

\author{
James F. Tammen ${ }^{1}$ \\ Department of Plant Pathology, The Pennsylvania State University, University \\ Park, PA 16802
}

Additional index words. Lilium longiflorum, bolting, vernalization, flower initiation

\begin{abstract}
In the commercial development of an innovative process for the production of pathogen-indexed Easter lilies (Lilium longiflorum Thunb.) in less than a year, it became desirable to quantify the cooling period so that the time of flower induction/initiation could be determined. Based upon studies of forcing flowering plants from bulbs, I hypothesized that cooling could be quantified using the cool temperature unit (CTU), defined as $1{ }^{\circ} \mathrm{C}$ below $21^{\circ} \mathrm{C}$ for 1 hour, and the warm temperature unit (WTU), defined as $1^{\circ} \mathrm{C}$ above $21^{\circ} \mathrm{C}$ for 1 hour. The purpose of these studies was to determine if the hypothesis was valid. With 'Nellie White' Easter lily, it was determined that cooling could be quantified as hypothesized. The minimum threshold number of CTU that would induce flowering in at least one plant of the test population after exposure to long days was between 1200 and 2400, whereas the threshold number of CTU that would induce flowering in $100 \%$ of the population was 3600 . The optimum threshold, i.e., the number of CTU that would result in the best market quality, was estimated to be 4800 . The studies demonstrate that market quality, pathogen-indexed flowering potted Easter lilies growing continuously from bulblets can be produced in about 1 year, and that the cooling required to sensitize the plants to long days, which is central to the success of the fast production process, is quantifiable.
\end{abstract}

An innovative process for the production of Easter lily was first reported in 1986 (Tammen et al., 1986). The process was based partly on observations made in 1961 and 1962 in connection with the production of pathogenindexed plants for studies on Easter lily root $\operatorname{rot}$ (Tammen and Criley, unpublished). Bulblets that were culture-indexed, propagated in tissue culture in Fall 1961, and grown continuously in the greenhouse at $21{ }^{\circ} \mathrm{C}$ day $/ 18^{\circ} \mathrm{C}$ night minimum temperatures flowered in Spring 1962 , less than one year from propagation. The flowering plants $(\approx 200)$ were of market quality.

In 1982, some 20 years later, research was begun by Oglevee Associates (Connellsville, $\mathrm{Pa}$.) to determine the feasibility of commercially producing pathogen-indexed Easter lilies from tissue cultured, leaf or scale propagated bulblets in less than one year. This was termed the fast production process. In the intervening years, several workers beginning with Waters and Wilkins (Waters, 1966; Waters and Wilkins, 1967) demonstrated that plants grown from non- or partially vernalized Easter lily bulbs

Received for publication 11 June 2001. Accepted for publication 22 Apr. 2002. This paper is dedicated to the memory of J. Robert Oglevee, partner in the endeavor to develop a new production system for pathogen-indexed Easter lilies, and friend and colleague of almost 40 years. I wish to thank Harold F. Wilkins for his valued advice during these and related studies. Sincere appreciation is also expressed to F.W. Zettler and T. C. Deng for virus indexing, to Richard Craig for assistance in statistical analyses of the data, and to Richard Craig and E. Jay Holcomb for assistance in manuscript preparation.

${ }^{1}$ Adjunct Professor. Present address: 326 Spruce Street, Philadelphia, PA 19106 would flower if grown at temperatures below $21^{\circ} \mathrm{C}$ and then exposed to long days (LD), thus showing that LD can substitute for cooling in the vernalization process for lilies grown from bulbs. The fast production process for potted Easter lilies was described and patented in 1986 (Oglevee et al., 1986a, 1986b; Tammen et al., 1986). A brief description of the process follows. Ten-week-old, pathogen-indexed bulblets were propagated in tissue culture (van Aartrijk et al., 1983) and maintained at $21^{\circ} \mathrm{C}$ and 8 -h photoperiods so that, after cooling to break propagation-induced dormancy (Stimart et al., 1982), they would grow in the hypogeous form, producing scales and scale leaves first and then undergoing a transition to produce stems and leaves (van Tuyl, 1983). While growing to produce scales and scale leaves, these plants are not sensitive to photoperiod even if cooled beforehand (Tammen, unpublished). After transition to stems and leaves, the plants are sensitive to photoperiod but grow in a rosetted, vegetative form until they are cooled and subsequently exposed to LD. In the Oglevee Associates studies, plants were cooled in a greenhouse at $18{ }^{\circ} \mathrm{C}$ day $/ 16{ }^{\circ} \mathrm{C}$ night minimum. This method is not unlike that of controlled temperature forcing of lilies grown from bulbs (De Hertogh et al., 1969). Long days are then provided using standard techniques (Weiler and Langhans, 1968b). Given a sufficient amount of cooling and LD, bolting occurs, flowers initiate, and ultimately the plants flower. Although the exact timing of the process varies depending upon production procedures as well as the calendar date for Easter, it usually begins with propagation during March/April and ends with Easter of the following year. Subsequent reports on similar processes have been made (Higgens and Stimart, 1990; Holcomb et al., 1995; Wickremesinhe et al., 1994).

As the Oglevee studies progressed, it became evident that the cooling period required to sensitize plants to LD needed to be quantified. Greenhouse temperatures during the cooling period vary from year to year. Plants will not flower if cooling is insufficient, whereas too much cooling will reduce quality. Field grown Easter lily bulbs exhibit similar responses when forced (Dole and Wilkins, 1994; Langhans and Weiler, 1971; Roh and Wilkins, 1973, 1977a; Weiler and Langhans, 1968a, 1972; Wilkins and Waters, 1970).

In addition, a long-term goal of the project was to produce flowering potted Asiatic and Oriental hybrid lilies throughout the year. This goal requires year-round regulation of flowering using the cooling/LD fast production process, which, as with Easter lilies, would necessitate quantification of cooling.

Weiler and Langhans (1968a, 1968b) demonstrated that cooling of 'Ace' Easter lily bulbs is vernalization and has both qualitative and quantitative effects. Miller and Kiplinger (1966a, 1966b) reported that partially vernalized bulbs could be devernalized. Langhans and Weiler (1971) and Weiler and Langhans (1968a) showed that temperatures below $21{ }^{\circ} \mathrm{C}$ are vernalizing and those above $21^{\circ} \mathrm{C}$ are devernalizing with bulbs of 'Ace' Easter lily. Several workers (Dole and Wilkins, 1994; Roh and Wilkins, 1973; Waters, 1966; Waters and Wilkins, 1967; Weiler and Langhans, 1968b; Weiler and Langhans, 1972; Wilkins and Waters, 1970; Wilkins et al., 1968) have demonstrated that partially vernalized bulbs will flower when exposed to LD and, therefore, that LD can partially substitute for cooling in the vernalization process. Roh and Wilkins suggested that LD could substitute for cold on a week-for-week basis (Roh and Wilkins, 1973), but later work by Dole and Wilkins (1994) refuted this claim. Roh and Wilkins (1977a, 1977c) concluded that a night interruption (NI) of $5 \mathrm{~h}$ is more effective than day extension and that $30 \mathrm{LD}$ were most effective in inducing flowering of 'Nellie White' Easter lily. They also determined that with a $16 \mathrm{~h} \mathrm{LD}$, $21{ }^{\circ} \mathrm{C}$ day $/ 13^{\circ} \mathrm{C}$ night is optimum from shoot emergence to flower bud initiation, and that a night temperature (NT) of $7.2^{\circ} \mathrm{C}$ followed by one of $15.6{ }^{\circ} \mathrm{C}$ is optimum for early flowering and flower numbers (Roh and Wilkins, 1977b). Weiler and Langhans (1968a) thought that plants growing from nonvernalized bulbs could be vernalized as they grew. Based on the aforementioned studies, I hypothesized that the cooling of plants grown continuously from bulblets could be quantified through the use of cool or warm temperature units, wherein a cool temperature unit (CTU) is equal to $1^{\circ} \mathrm{C}$ below $21^{\circ} \mathrm{C}$ for one $\mathrm{h}$ and a warm temperature unit (WTU) is equal to $1{ }^{\circ} \mathrm{C}$ above $21^{\circ} \mathrm{C}$ for one $\mathrm{h}$. In addition, it was hypothesized that Lilium plants continuously perceive and accumulate temperature inputs which regulate vegetative/reproductive growth. WTU are accumulated as units for vegetative growth, i.e. nonvernalizing, and CTU are accumulated for reproductive growth, i.e., vernalizing. CTU 
will accumulate up to a threshold amount, after which flower induction/initiation occurs. Until this threshold is reached, WTU may reverse the process. WTU, however, cannot be accumulated beyond the point of complete devernalization. The objectives of this research were to determine if the cooling required to induce flowering in the Easter lily is quantifiable using the described fast production process and stated hypotheses and, if so, the amount of cooling that will result in $100 \%$ high-quality, flowering plants.

\section{Materials and Methods}

General procedures. Field-grown bulbs of 'Nellie White' were obtained from Hastings Bulb Growers, Brookings, Ore., in early Dec. 1992. Bulbs were washed and then scaled, and the developing meristems culture-indexed in tissue culture (van Aartrijk et al., 1983). After 10 weeks, bulblets which developed from the meristem tips were harvested and cooled at 4 ${ }^{\circ} \mathrm{C}$ for 2 weeks to break propagation-induced dormancy (Stimart et al., 1982). From these bulblets, mother plants for the eventual propagation of bulblets for the experiments were grown as single plant units on raised benches in a greenhouse until May 1993 when they were indexed for Cucumber mosaic virus, Tulip break virus, and Lily symptomless virus (Deng, 1995). Those that indexed free of these viruses were retained and the bulbs were used subsequently to propagate bulblets for Expt. 1 and to establish mother plants from which bulblets were propagated for Expt. 2. Sprouted, culture-virus indexed bulblets for Expt. 3 were provided by Oglevee, Connellsville, $\mathrm{Pa}$.

Bulblets for Expts. 1 and 2, grown from meristem tips measuring $0.5-1.0 \mathrm{~cm}$ diameter, were cooled at $4 \pm 2{ }^{\circ} \mathrm{C}$ for two weeks and then planted and sprouted in a greenhouse on raised benches in 96-cell trays (Cord Insert 812, Park Seed, Greenwood, S.C.) filled with a soilless growing medium (Fafard Plug Mix; Conrad Fafard, Springfield, Mass.). Water, containing $1.3 \mathrm{~g} \cdot \mathrm{L}^{-1} 20 \mathrm{~N}-20 \mathrm{P}-20 \mathrm{~K}$ soluble fertilizer (Peters Professional; The Scotts Co., Marysville, Ohio), was applied as needed. Bulblets for Expt. 1 were propagated in 1994 and those for Expt. 2 in 1995.

After $\approx 6$ weeks, the plantlets were transplanted into 0.6-L plastic pots filled with a soilless growing medium (Fafard Grower Mix No. 2.). The plants were watered and fertilized on alternate weeks with either $1.9 \mathrm{~g} \cdot \mathrm{L}^{-1}$ of calcium nitrate plus $0.9 \mathrm{~g} \cdot \mathrm{L}^{-1}$ potassium nitrate or 2.5 $\mathrm{g} \cdot \mathrm{L}^{-1} 21 \mathrm{~N}-5 \mathrm{P}-20 \mathrm{~K}$ soluble fertilizer (Miracle Grow Excel, The Scotts Co.) (Wilkins, 1980) and, in addition, were watered as needed. For all three experiments, the minimum day/night temperature was set at $21^{\circ} \mathrm{C}$ and the lighting was natural. Thus, the plants were grown under conditions which would preclude the accumulation of CTU.

Experiments were initiated when plants were growing in the rosette form, i.e., after plants had gone through the transition from producing scales and scale leaves to producing stems and leaves. Plant size in terms of numbers of leaves at this time differed between experiments but did not significantly differ between treatments within each experiment, except that plants in the noncooled treatment of Expt. 1 had significantly fewer (avg. 17) than the other treatments (avg. 26). Cooling treatments were applied in a growth chamber (modelE-540U Dl; Percival Scientific, Boone, Iowa) with cool-white fluorescent lamps providing $29 \mu \mathrm{mol} \cdot \mathrm{m}^{-2} \cdot \mathrm{s}^{-1}$ for $8 \mathrm{~h}$ daily. Plants were placed into the chamber for the times and temperatures necessary for the requisite CTU dosages. Specific time and temperature exposures for each experiment is provided below, but all plants in each experiment were cooled at the same temperature in the same chamber. Following cooling treatments, LDs were given in the greenhouse using either incandescent or sodium high intensity discharge (HID) lamps at 3 or $2 \mu \mathrm{mol} \cdot \mathrm{m}^{-2} \cdot \mathrm{s}^{-1}$, respectively, for $5 \mathrm{~h}$ daily (2200-0300 HR).

Uncooled (control) plants were placed under LD immediately, whereas treated plants were placed under LD for $28-30 \mathrm{~d}$ following their respective treatments. The minimum greenhouse temperature for forcing was 21 ${ }^{\circ} \mathrm{C}$ to prevent any further accumulation of CTU. Otherwise, standard growing/forcing procedures were used for growing plants (Wilkins, 1980).

After the cooling/LD treatments, plants were placed on a single, raised bench in the greenhouse at the Pennsylvania State Univ., University Park. They were grouped by cool treatment with plants within a cool treatment randomized.

Superanova (Abacus Concepts, Berkeley, Calif.) was used to compute analyses of variance (ANOVA). Fisher's protected least significant difference (LSD) was used to separate means when $F$ ratios in the ANOVA were significant. Variables analyzed included number of days to bolt, days to first visible flower bud, days to first open flower bud, and days to first and last open flower, beginning with the LD initiation dates for each treatment. Number of leaves to start, percentage of bolted plants, percentage of plants flowering, numbers of flowers and leaves, and stem length were also analyzed. Data for plants which did not flower were taken on the date when the last flowering plant in each experiment reached anthesis. All of the leaves of nonflowering plants were removed and counted, and the apical meristems examined macroscopically for evidence of flower bud initiation (Pfeiffer, 1935). Microsoft Excel Version 5 (Microsoft Corp., Redmond, Wash.) was used to compute the correlation coefficient in Expt. 3.

Expt. 1. The objective of this experiment, was to determined the threshold number of CTU required to induce $100 \%$ flowering in the test population. After cooling to break propagation-induced dormancy, bulblets were sprouted beginning 17 Mar. 1994, transplanted to 0.6 -L pots on 26 May and grown until 16 Jan. 1995 when treatments of $0,600,1200$, and 4800 CTU were applied as 10 -h days at $15 \pm 1$ ${ }^{\circ} \mathrm{C}$ and 14-h nights at $12 \pm 1{ }^{\circ} \mathrm{C}$, or $186 \mathrm{CTU}$ daily. There were nine plants per treatment and each plant averaged 22.5 (range 15-54) leaves. Following cold treatments, plants were exposed to $28 \mathrm{LD}$ using sodium HID lamps in the greenhouse beginning on $16 \mathrm{Jan}$. The minimum forcing temperature was set for $21^{\circ} \mathrm{C}$, but day/night temperatures occasionally ranged as high as $27^{\circ} \mathrm{C}$ and as low as $15^{\circ} \mathrm{C}$.

Expt. 2. The purpose of this experiment was to determine the number of CTU that would result in the highest-quality flowering potted plants, that is, the optimum threshold. Bulblets were sprouted beginning 2 Feb. 1995 and plantlets were transplanted into 0.6 -L pots 22 July and were grown until 20 Sept. when cooling treatments of $3600,4800,6000$ and 7200 CTU were begun. The temperature regime was 10 -h days at $12 \pm 1{ }^{\circ} \mathrm{C}$ and 14 -h nights at $7 \pm 1{ }^{\circ} \mathrm{C}$ and supplied $286 \mathrm{CTU}$ daily. There were eight plants per treatment, averaging 27 (range 17-39) leaves per plant. Following cooling treatments, all plants were exposed to 30 LD using incandescent lamps. LD began on 6 Oct. 1995. Temperatures occasionally ranged as high as $36^{\circ} \mathrm{C}$ and as low as $15^{\circ} \mathrm{C}$.

Expt. 3. This experiment was conducted to determine more precisely the minimum threshold, threshold, and optimum threshold CTU dosages. Plantlets growing in the hypogeous form in 40-cell Rubber Dirt plugs (Oglevee, Connellsville, $\mathrm{Pa}$ ) were received and planted into 0.6-L pots on 9 May 1996. They were grown until 23 Aug., when cooling treatments of $0,600,1200,2400$, and 4800 CTU were applied using 8-h days and a constant day/night temperature of $15 \pm 1{ }^{\circ} \mathrm{C}$, or 144 CTU daily. There were nine plants per treatment averaging 20 (range 16-29) leaves per plant. Following cooling treatments, each plant received $28 \mathrm{LD}$ beginning 23 Aug. using sodium HID lamps. Maximum day temperatures from mid-August to mid-October exceeded 27 ${ }^{\circ} \mathrm{C}$ and ranged as high as $39^{\circ} \mathrm{C}$.

\section{Results}

Expt. 1. None of the uncooled plants bolted or flowered, but continued to grow in the rosette form typical of nonvernalized Easter lilies (Fig. 1A). Plants given 600 or 1200 CTU bolted by the end of the experiment, but did not initiate flowers. All plants given 4800 CTU bolted and initiated flowers, confirming that Easter lilies grown continuously from bulblets can be vernalized and induced to flower when given an appropriate amount of cooling followed by LD, and also showing that the cooling requirement can be quantified (Table 1). With 4800 CTU, plants flowered within 110 days and were of marketable quality, with each plant $\approx 52 \mathrm{~cm}$ in height and yielding eight flowers (Table 1; Fig. 1B). Floral initiation did not occur when plants received 1200, but did ensue after exposure to 4800 CTU. With $4800 \mathrm{CTU}, 36 \mathrm{~d}$ lapsed from the first to the last open flower among all plants in the treatment group.

Expt.2.All of the plants bolted and flowered at every CTU dosage. All treatments resulted in plants of acceptable quality in terms of number of days to flower, numbers of flowers, and plant height (Table 2). Application of 6000 and 7200 CTU resulted in fewer flowers compared to plants receiving 3600 CTU. The number of flowers at 3600 CTU was signifi- 
Table 1. Effect of quantified cooling on the growth and flowering of nonvernalized, pathogen-indexed 'Nellie White' Easter lily. Plants were kept in controlled environment chambers set at $15^{\circ} \mathrm{C}, 10$-h days and $12{ }^{\circ} \mathrm{C}, 14$-h nights (Total dosage of $186 \mathrm{CTU} /$ day).

\begin{tabular}{lcccccccc}
\hline Treatment & $\begin{array}{c}\text { Plants } \\
\text { bolting } \\
(\%)^{\mathrm{y}}\end{array}$ & $\begin{array}{c}\text { Plants } \\
\text { flowering } \\
(\%)^{\mathrm{y}}\end{array}$ & $\begin{array}{c}\text { Days to } \\
\text { visible } \\
\text { bud }\end{array}$ & $\begin{array}{c}\text { Days to } \\
\text { first open } \\
\text { flower }\end{array}$ & $\begin{array}{c}\text { Flowering } \\
\text { period }^{\mathrm{x}}\end{array}$ & $\begin{array}{c}\text { No. of } \\
\text { flowers }\end{array}$ & $\begin{array}{c}\text { Stem } \\
\text { length } \\
(\mathrm{cm})\end{array}$ & $\begin{array}{c}\text { No. of } \\
\text { leaves }\end{array}$ \\
\hline 0 & 100 & 0 & --- & --- & --- & --- & $28 \mathrm{c}^{\mathrm{w}}$ & $160 \mathrm{bc}$ \\
600 & 100 & 0 & --- & --- & --- & --- & $34 \mathrm{bc}$ & $170 \mathrm{~b}$ \\
1200 & 100 & 0 & --- & --- & --- & --- & $37 \mathrm{~b}$ & $200 \mathrm{a}$ \\
4800 & 100 & 100 & 78 & 110 & 36 & 8 & $51 \mathrm{a}$ & $139 \mathrm{c}$ \\
Significance & --- & --- & --- & --- & --- & --- & $*$ & $*$ \\
\hline
\end{tabular}

${ }^{\mathrm{z}} \mathrm{A}$ cool temperature unit (CTU) is defined as $1{ }^{\circ} \mathrm{C}$ below $21.0^{\circ} \mathrm{C}$ for $1 \mathrm{~h}$.

yine plants per treatment.

${ }^{x}$ Number of days from opening of the first flower of the first plant to flower to the first open flower on the last plant to flower.

${ }^{w}$ Mean separation within columns by Fishers protected LSD at $P \leq 0.05$ or 0.01 .

*Significant at $P \leq 0.05$
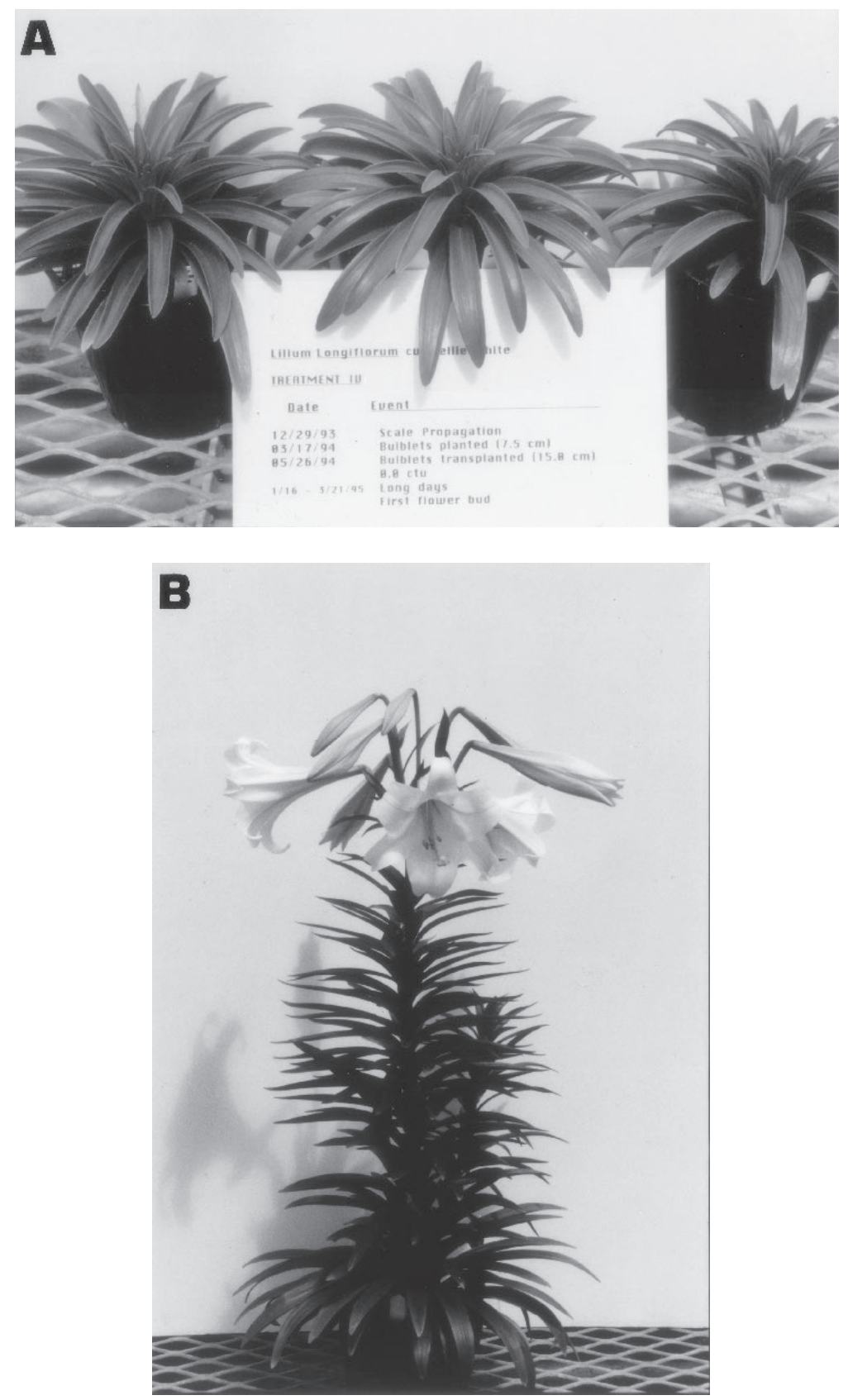

Fig. 1. Quantification of cooling in growing plants of Lilium longiflorum Thunb. cv. Nellie White, Expt. 1. (A) Untreated control; zero cool temperature units (CTU), but exposed to 28 long days of $5 \mathrm{~h}$ night interruption, 1000-0300, beginning 12 Jan. 1995 and showing rosetted growth typical of nonvernalized plants growing vegetatively; (B) $4800 \mathrm{CTU}$ treatment, followed by exposure to 28 long days of $5 \mathrm{~h}$ night interruption, 1000-0300, beginning 9 Feb. 1995. cantly greater than at $4800 \mathrm{CTU}$. There was an inverse relationship between number of days to open flower and CTU dosage. At 4800 CTU, $109 \mathrm{~d}$ elapsed between the onset of LD and the first open flower, a result similar to that observed in Expt. 1. Sixty nine, 29, 18, and $18 \mathrm{~d}$ elapsed from the first to last open flower at $3600,4800,6000$, and $7200 \mathrm{CTU}$, respectively. There were no significant differences in stem length among treatments. The number of leaves decreased with increasing CTU. There was a significantly greater number of leaves at 3600 than at 6000 or $7200 \mathrm{CTU}$, indicating that flower induction/initiation occurred earlier at 7200 than 3600 CTU.

Expt. 3. Uncooled plants did not bolt or flower (Table 3). Percentage of plants that bolted and percentage of plants that flowered increased as CTU dosage increased. Twentyone days lapsed from first to last open flower. However, in contrast with the 110 and 109 days from the onset of LD to first open flower with Expts. 1 and 2, respectively, the lapsed time was just $66 \mathrm{~d}$ for plants receiving $4800 \mathrm{CTU}$ (Tables 1,2 , and 3). Stem length of those plants which bolted and flowered did not differ significantly between treatments. However, the number of leaves decreased with increasing CTU.

\section{Discussion}

The results of these studies support the hypothesis that cooling to induce flowering after exposure to LD can be quantified in $L$. longiflorum 'Nellie White' using CTU, and, when appropriate, WTU. The data indicate that it is feasible not only to regulate flower induction/initiation, but also to regulate plant quality.

Uncooled plants and those given $600 \mathrm{CTU}$ did not flower when exposed to LD, but $100 \%$ of those given at least 3600 CTU flowered (Tables 1-3). In Expt. 1, none of the plants given 1200 CTU flowered, whereas in Expt. $3,22 \%$ and $33 \%$ of the plants flowered after receiving 1200 and 2400 CTU, respectively. These results indicate that the threshold number of CTU for flower induction was 3600 CTU and that the minimum threshold was between 1200 and 2400 CTU. The optimum threshold was difficult to ascertain, because forcing temperatures used in all experiments were above 21 ${ }^{\circ} \mathrm{C}$, which is higher than that recommended for commercial forcing (Wilkins, 1980). However, a comparison of the data from these experiments, specifically, days to flower, days from first to last open flower, flower number and plant height, suggest that the optimum threshold is $\approx 4800$ CTU (Fig. 1B).

Essentially the same number of days elapsed between the first LD and the first open flower in Expts. 1 and 2, indicating that it may be feasible to estimate the flowering date based upon the date of lighting following the optimum cooling threshold. The fact that significantly less time lapsed between the first LD and the first open flower in Expt. 3 would seem to mitigate against such a conclusion. However, Expt. 3 was carried out in the summer and early fall when greenhouse temperatures were much higher than in Expts. 1 and 2, which were 
Table 2. Effect of quantified cooling on the growth and flowering of nonvernalized, pathogen-indexed plants of 'Nellie White' Easter lily (Expt. 2). Plants were kept in controlled environment chambers set at $12{ }^{\circ} \mathrm{C}, 14$-h days and $7{ }^{\circ} \mathrm{C}, 10$-h nights (total dosage of $266 \mathrm{CTU} /$ day).

\begin{tabular}{lcccccccc}
\hline $\begin{array}{l}\text { Treatment } \\
(\text { CTU })^{z}\end{array}$ & $\begin{array}{c}\text { Plants } \\
\text { Bolting } \\
(\%)^{\mathrm{y}}\end{array}$ & $\begin{array}{c}\text { Plants } \\
\text { flowering } \\
(\%)^{\mathrm{y}}\end{array}$ & $\begin{array}{c}\text { Days to } \\
\text { visible } \\
\text { bud }\end{array}$ & $\begin{array}{c}\text { Days to } \\
\text { first open } \\
\text { flower }\end{array}$ & $\begin{array}{c}\text { Flowering } \\
\text { period }^{\mathrm{x}}\end{array}$ & $\begin{array}{c}\text { No. of } \\
\text { flowers }\end{array}$ & $\begin{array}{c}\text { Stem } \\
\text { length } \\
(\mathrm{cm})\end{array}$ & $\begin{array}{c}\text { No. of } \\
\text { leaves }\end{array}$ \\
\hline 3600 & 100 & 100 & $88 \mathrm{a}^{\mathrm{w}}$ & $128 \mathrm{a}$ & 69 & $6 \mathrm{a}$ & 44 & $101 \mathrm{a}$ \\
4800 & 100 & 100 & $74 \mathrm{~b}$ & $109 \mathrm{~b}$ & 29 & $5 \mathrm{ab}$ & 47 & $91 \mathrm{ab}$ \\
6000 & 100 & 100 & $62 \mathrm{bc}$ & $97 \mathrm{bc}$ & 18 & $4 \mathrm{~b}$ & 47 & $83 \mathrm{bc}$ \\
7200 & 100 & 100 & $55 \mathrm{c}$ & $89 \mathrm{c}$ & 18 & $4 \mathrm{~b}$ & 44 & $78 \mathrm{c}$ \\
Significance & --- & --- & $* *$ & $* *$ & --- & $*$ & $*$ & $*$ \\
\hline
\end{tabular}

${ }^{\mathrm{z}} \mathrm{A}$ cool temperature unit (CTU) is defined as $1{ }^{\circ} \mathrm{C}$ below $21^{\circ} \mathrm{C}$ for $1 \mathrm{~h}$.

${ }^{y}$ Eight plants per treatment.

${ }^{x}$ Number of days from opening of the first flower of the first plant to flower to the first open flower on the last plant to flower.

"Mean separation within columns by Fisher's protected LSD at $P \leq 0.05$ or 0.01 .

,** Significant at $P \leq 0.05$ or 0.01 , respectively.

Table 3. Effect of quantified cooling on the growth and flowering of nonvernalized, pathogen-indexed 'Nellie White' Easter lily. Plants were kept in controlled environment chambers using 8-h days and at a constant $15^{\circ} \mathrm{C}$ (total dosage of $144 \mathrm{CTU} /$ day). set at $15^{\circ} \mathrm{C}$ (total dosage of $144 \mathrm{CTU} /$ day).

\begin{tabular}{lcccccccc}
\hline $\begin{array}{l}\text { Treatment } \\
(\mathrm{CTU})^{\mathrm{z}}\end{array}$ & $\begin{array}{c}\text { Plants } \\
\text { bolting } \\
(\%)^{\mathrm{y}}\end{array}$ & $\begin{array}{c}\text { Plants } \\
\text { flowering } \\
(\%)^{\mathrm{y}}\end{array}$ & $\begin{array}{c}\text { Days to } \\
\text { visible } \\
\text { bud }\end{array}$ & $\begin{array}{c}\text { Days to } \\
\text { first open } \\
\text { flower }\end{array}$ & $\begin{array}{c}\text { Flowering } \\
\text { period }^{\mathrm{x}}\end{array}$ & $\begin{array}{c}\text { No. of } \\
\text { flowers }\end{array}$ & $\begin{array}{c}\text { Stem } \\
\text { length } \\
(\mathrm{cm})\end{array}$ & $\begin{array}{c}\text { No. of } \\
\text { leaves }\end{array}$ \\
\hline 0 & 0 & 0 & --- & --- & --- & --- & --- & $129 \mathrm{a}^{\mathrm{w}}$ \\
600 & 33 & 0 & --- & -- & --- & -- & 36 & $135 \mathrm{a}$ \\
1200 & 44 & 22 & $76 \mathrm{a}$ & $110 \mathrm{a}$ & 77 & 3.5 & 51 & $100 \mathrm{ab}$ \\
2400 & 56 & 33 & $38 \mathrm{~b}$ & $68 \mathrm{ab}$ & 36 & 3.2 & 32 & $86 \mathrm{bc}$ \\
4800 & 100 & 100 & $34 \mathrm{~b}$ & $66 \mathrm{~b}$ & 21 & 2.5 & 44 & $76 \mathrm{c}$ \\
Significance & ---- & --- & $*$ & $*$ & --- & NS & NS & $*$ \\
\hline
\end{tabular}

${ }^{2} \mathrm{~A}$ cool temperature unit (CTU) is defined as $1{ }^{\circ} \mathrm{C}$ below $21^{\circ} \mathrm{C}$ for $1 \mathrm{~h}$.

${ }^{y}$ Nine plants per treatment.

${ }^{x}$ Number of days from opening of the first flower of the first plant to flower to the first open flower on the last plant to flower within a treatment.

${ }^{\text {w } M e a n ~ s e p a r a t i o n ~ b e t w e e n ~ c o l u m n s ~ b y ~ F i s h e r s ~ p r o t e c t e d ~ L S D ~ a t ~} P \leq 0.05$ or 0.01 .

Ns, *, "** Nonsignificant or significant at $P \leq 0.05$ or 0.01 , respectively.

conducted in the winter. Although this could explain the shorter forcing times encountered in Expt. 3, it is concluded that although the time of flower induction/initiation can be precisely determined, actual flowering dates will depend upon the forcing environment. For this reason, the use of leaf counting to determine flowering dates (Wilkins, 1980) would be as useful to the fast production system as it is to the commercial forcing of Easter lily bulbs.

The length of time to flower after cooling and LD treatments is important for Easter lilies because plants must flower by a specific date that varies each year. In these experiments, there were significant differences in the number of days to flower among cooling treatments, with the number of days decreasing with increased CTU dosages. Data from Expt. 3 (Table 3) show a correlation coefficient of -0.89 between days to flower and the number of CTU. The time to first open flower at 4800 CTU was 110 and 109 d for Expt. 1 and 2, respectively, but only $66 \mathrm{~d}$ for Expt. 3. However, in Expt. 3, forcing temperatures, particularly during the early period, were well above 26 ${ }^{\circ} \mathrm{C}$ and ranged as high as $39^{\circ} \mathrm{C}$. It has been shown for L. longiflorum 'Croft' that higher temperature regimes will significantly reduce time to flower and the number of flowers (Smith and Langhans, 1962).

The number of days over which the plants flowered, another important market constraint, was too great under the conditions of these experiments but decreased with increased CTU dosage. At 4800 CTU, 36, 29, and $21 \mathrm{~d}$ lapsed from the first to the last open flower in Expt. 1,2 , and 3 , respectively (Tables $1-3$ ).

These experiments confirm that market quality, pathogen-indexed potted Easter lilies can be produced in about a year, beginning with a hypogeous-sprouted bulblet measuring $5.0-10.0 \mathrm{~mm}$ in diameter, and then growing the plants continuously. This fast production system has been under commercial development at Oglevee, since 1983. Cooling prior to LD was accomplished by setting minimum day/night temperatures (i.e., $18.3 / 15.5^{\circ} \mathrm{C}$ ) so that 4800 CTU were accumulated. Since 1996, quantification of the accumulated CTU (e.g., CTU-WTU) has been accomplished using temperature sensors placed near the vegetative growing point (Faust and Heins, 1998) and a computer program designed to accumulate CTU according to these hypotheses (Tammen, 1991; Tammen et al., 1996). After the requisite CTU had accumulated, LD were initiated so that flowering would coincide with Easter. Thus, the quantification of cooling determined experimentally has been applied to commercial production of Easter lilies.

It would seem that lily researchers and producers of bulbs and forcers would benefit from using the CTU-WTU concept for monitoring and quantifying the growth processes in Lilium. This would provide a means of comparing studies, crops, or both, within and between production years, which is not currently possible. It would allow bulb producers to provide quantified information to researchers and forcers on the actual vernalization status of field-grown bulbs at the time they are dug and shipped. Such information would be of practical value to researchers, who could then either continue to vernalize or to de-vernalize to suit the purpose of their studies. It would be of equal value to forcers in their efforts to vernalize bulbs to optimize quality and to flower the crop on time for Easter. This quantification process could be useful also to the development of innovative approaches to year-round forcing of flowering potted lilies.

\section{Literature Cited}

De Hertogh, A.A., W.H. Carlson, and S. Kays. 1969. Controlled temperature forcing of planted lily bulbs. J. Amer. Soc. Hort. Sci. 94:433-436.

Deng, T.C. 1995. Development of reliable protocols for detecting and controlling lily viruses. $\mathrm{PhD}$ Diss., Univ. of Florida, Gainesville.

Dole, J.M. and H.F. Wilkins. 1994. Interaction of bulb vernalization and shoot photoperiod on 'Nellie White' Easter lily. HortScience 29:143-145.

Faust, J.E. and R.D. Heins. 1998. Modeling shoot-tip temperature in the greenhouse environment. J. Amer. Soc. Hort. Sci. 123:208-214.

Higgens, W.S. and D. P. Stimart. 1990. Influence of in vitro generation temperature and post in vitro cold storage duration on growth response of Lilium longiflorum bulblets. J. Amer. Soc. Hort. Sci. 115:930-933.

Holcomb, J., R. Arteca, and E. Wickremesinhe. 1995. High-tech Easter lilies. GrowerTalks 58[10]:68-70, 72.

Langhans, R.W. and T.C. Weiler. 1971. The effects of warm storage on the growth and flowering of Lilium longiflorum ( Thunb.) 'Ace'. Acta Hort. 23:66-70.

Miller, R.O. and D.C. Kiplinger. 1966a. Interaction of temperature and time of vernalization on Northwest Easter lilies. Proc. Amer. Soc. Hort. Sci. 88:635-645.

Miller, R.O. and D.C. Kiplinger. 1966b. Reversal of vernalization in Northwest Easter lilies. Proc. Amer. Soc. Hort. Sci. 88:646-650.

Oglevee, J.R., J.F. Tammen, and W. O'Donovan. 1986a. Lily processes. U.S. Patent 4,570,397.

Oglevee, J.R., J.F. Tammen, and W. O’Donovan. 1986b. Lily products. U.S. Patent $4,604,824$.

Pfeiffer, N.E. 1935. Development of the floral axis and new bud in imported Easter lilies. Contrib. Boyce Thompson Inst. 3:311-321.

Roh, S.M. and H.F. Wilkins 1973. The influence and substitution of long days for cold treatments on growth and flowering of Easter lilies (Lilium longiflorum Thunb.) Georgia and Nellie White. Flor. Rev. 153(3960):19-21.

Roh, S.M. and H.F. Wilkins. 1977a. The effects of bulb vernalization and shoot photoperiod treatments on growth and flowering of Lilium longiflorum Thunb. cv. Nellie White. J. Amer. Soc. Hort. Sci. 102:229-235.

Roh, S.M. and H.F. Wilkins. 1977b. Temperature and photoperiod effect on flower numbers in Lilium longiflorum Thunb. J. Amer. Soc. Hort. Sci. 102:235-242.

Roh, S.M. and H.F. Wilkins 1977c. Influence of interrupting the long day inductive treatments on growth and flower numbers of Lilium longiflorum Thunb. J. Amer. Soc Hort. Sci. 102:253-255

Stimart, D.P., P.D. Asher, and H.F. Wilkins. 1982. Overcoming dormancy in Lilium longiflorum bulblets produced in tissue culture. J. Amer. Soc. Hort. Sci. 107:1004-1007.

Smith, D.R. and R.W.Langhans. 1962. The influence of day and night temperature on the growth and flowering of the Easter lily (Lilium longiflorum 
Thunb. var. Croft). Proc. Amer. Soc. Hort. Sci. 80:593-598.

Tammen, J.F. 1991. Process for the production of Lilium species. U.S. Patent 5,058,318.

Tammen, J.F., J.R. Oglevee, E.J. Oglevee, and L. Duffy 1986. A new process for producing pathogen-indexed Easter lilies. GrowerTalks 50 (3):62, 65-66.

Tammen, J.F., F.W. Zettler, T.A. Nell, J.E. Barrett, R. Leonard, and D.S. Wampler. 1996. Studies on the commercial production of pathogen-indexed Asiatic lily bulbs in the United States. Acta Hort. 430:189-197.

van Aartrijk, J., G.J. Blom-Barnhorn, and P.C.G. van der Linde. 1983. p. 535-576. In: P.V. Ammirato, D.R. Evans, W.R. Sharp, and P.S. Bajaj (eds.). Hdbk. of Plant Cell Culture, Vol. 5. Ornamental species. McGraw-Hill, New York.

van Tuyl,J.M. 1983. Effect of temperature treatments on the scale propagation of Lilium longiflorum
'White Europe' and 'Enchantment'. HortScience 18:754-756.

Waters, W.E. 1966. Light induces flowering in the Easter lily. Sunshine State (Florida) Agr. Res. Rpt. for 1966. p. 10-11.

Waters, W.E. and H.F. Wilkins. 1967. Influence of intensity, duration, and date of light on growth and flowering of uncooled Easter lily (Lilium longiflorum Thunb. 'Georgia'). Proc. Soc. Hort. Sci. 90:433-439.

Weiler, T.C. and R.W. Langhans. 1968a. Determination of vernalizing temperatures in the vernalization requirement of Lilium longiflorum (Thunb.) cv. Ace. Proc. Amer. Soc. Hort. Sci. 93:623-629.

Weiler, T.C., and R.W. Langhans. 1968b. Effect of photoperiod on the vernalization of Lilium longiflorum (Thunb.) cv. Ace. Proc. Amer. Soc. Hort. Sci. 93:630-639.

Weiler, T.C., and R.W. Langhans. 1972. Growth and flowering responses of Lilium longiflorum Thunb. 'Ace' to different daylengths. J. Amer. Soc. Hort. Sci. 97:176-177.

Wickremesinhe, E.R.M., E.J. Holcomb, and R.N. Arteca. 1994. A practical method for the production of flowering Easter lilies from callus cultures. Scientia Hort. 60:143-152.

Wilkins, H.F. 1980. Easter lilies. p. 327-352. In: R.A. Larson (ed.). Introduction to floriculture. Academic, New York.

Wilkins, H.F. and W.E. Waters. 1970. The interaction of temperature and photoperiod on growth and flowering of Lilium longiflorum Thunb. cv. 'Nellie White'. Acta Hort. 23:48-57.

Wilkins, H.F., W.E. Waters, and R.E. Widmer 1968. Influence of temperature and photoperiod on growth and flowering of Easter lilies (Lilium longiflorum, Thunb. 'Georgia', 'Ace', and 'Nellie White'). Proc. Amer. Soc. Hort. Sci. 93:640-649. 